\title{
DIVERSITY OF ANTARCTIC MICROORGANISMS - POTENTIAL PRODUCERS OF BIOLOGICALLY ACTIVE SUBSTANCES
}

\section{T. O. Kondratiuk, T. V. Beregova, L. I. Ostapchenko}

Taras Shevchenko National University of Kiev, Ukraine, Volodimirsjka str. 64/13, e-mail: takbiofak@ukr.net

\begin{abstract}
Search for new producers of biologically active compounds that can be widely used in various fields of human activity is intense among the variety of organisms, habitats of which are connected with the extreme conditions of existence, including Antarctica. The purpose of this work was conducting relevant research on this topical issue. 25 isolation of pure cultures of microscopic fungi (species of Mortiriella, Mucor, Eurotium, Cladosporium, Fusarium, Geotrichum, Pseudogymnoascus, Penicillium, Phoma, Rhodotorula etc.) were obtained from the samples of mosses, lichens, soil and stones obtained from 18-20th Ukrainian Antarctic expedition (Galindez, Pitterman, and Yalur Islands). Among them Pseudogymnoascus pannorum and Mucor circinelloides are characterized by a pronounced activity to the synthesis of complex of biologically active lipids. 8 pure cultures of bacteria were also isolated that synthesize biologically active substances which can inhibit the growth of other microorganisms (pronounced antagonistic properties were observed). Collection of technologically advanced microorganisms replenished with new srains of microscopic fungi and bacteria - producers of biologically active compounds.
\end{abstract}

Різноманіття антарктичних мікроорганізмів - потенційних продуцентів біологічно-активних сполук Т. О. Кондратюк, Т. В. Берегова, Л. І. Остапченко

Реферат. Пошук нових продуцентів біологічно-активних сполук, які можуть широко застосовуватися в різних галузях людської діяльності, інтенсивно ведеться серед різноманіття мікроорганізмів, місця існування яких пов'язані з екстремальними умовами існування, зокрема в Антарктиді. Проведення відповідних досліджень 3 цього актуального питання становило мету даної роботи. Із досліджених зразків мохів, лишайників, грунту та каміння, отриманих у 18-20-й Українських антарктичних експедиціях (о. Галіндез, о. Піттерман, о. Ялур), ізольовано 25 чистих культур мікроскопічних грибів (види родів Mortiriella, Mucor, Eurotium, Cladosporium, Fusarium, Geotrichum, Pseudogymnoascus, Penicillium, Phoma, Rhodotorula та ін.). Серед них Pseudogymnoascus pannorum та Mucor circinelloides характеризуються яскраво вираженою активністю до синтезу комплексу біологічно активних ліпідів. Ізольовано також 8 чистих культур бактерій, що синтезують біологічно-активні речовини, здатні пригнічувати ріст інших мікроорганізмів (проявляють яскраво виражені антагоністичні властивості). Колекцію технологічно перспективних штамів мікроорганізмів поповнено новими видами мікроскопічних грибів бактерій - продуцентів біологічно активних сполук.

Разнообразие антарктических микроорганизмов - потенциальных продуцентов биологически-активных соединений

Т. А. Кондратюк, Т. В. Береговая, Л. И. Остапченко

Реферат. Поиск новых продуцентов биологически-активных соединений, которые могут широко использоваться в разных сферах человеческой деятельности, интенсивно ведется среди разнообразия микроорганизмов, места 
существования которых связаны с экстремальными условиями, в частности в Антарктиде. Проведение соответствующих научных исследований в этом актуальном направлении составляло цель данной работы. Изучение образцов мхов, лишайников, грунта и камней с антарктических островов Галіндез, Піттерман, Ялур (18-20-я Украинские антарктические экспедиции) позволило выделить 25 чистых культур микроскопических грибов (виды родов Mortiriella, Mucor, Eurotium, Cladosporium, Fusarium, Geotrichum, Pseudogymnoascus, Penicillium, Phoma, Rhodotorula и др.). Среди них Pseudogymnoascus pannorum и Mucor circinelloides характеризуются ярко выраженной активностью синтезировать комплекс липидов. Ізолировано также 8 чистых культур бактерий, которые синтезируют биологически-активные вещества, способные угнетать рост других микроорганизмов (проявляют ярко выраженные антагонистические свойства). Коллекцию технологически перспективных штаммов микроорганизмов пополнено новыми видами микроскопических грибов и бактерий продуцентов биологически-активных соединений.

Key words: Antarctic microorganisms, collection of technologically advanced microorganisms

\section{Introduction}

The development of biotechnology, which is based on the potential of microorganisms in obtaining biologically active substances (BAS), is one of the strategic directions of the modern world science. The strategy of finding new producers of BAS is based on the following principles: specificity (extreme) species (strain) locality, including those belonging to the region, which had previously been allocated to producers; taxonomic position of species (strain), its cultural-morphological, physiological, biochemical and molecular genetic features. These features microscopic fungi from extreme envinroement that can help them to survive and develop in conditions of extreme environmental factors, including Antarctica, are investigated to determine the mechanisms of microbial adaptation to the living conditions of their production and BAS [Kostadinova et al., 2009; Margesin et al., 2005; Nai et al., 2013]. Thus, among microscopic fungi, producers of BAS special attention deserve those that can remain viable and grow in extreme conditions, especially in Antarctica [Henriquez et al., 2013; Svahn et al., 2015], as they are powerful sources of potential metabolites with antimicrobial and antifungal activity that may be subject to the pharmaceutical industry. It was found that metabolites of the mycelium of fungi of Antarctic are capable of inhibiting the growth of Staphylococcus aureus [Henriquez et al., 2013]. Swedish researchers received new antifungal metabolite (amfoteritsyn) that exhibits activity against yeast fungus Candida albicans. The filamentous fungus Penicillium nalgiovense Laxa, derived from Antarctic samples is producer of amphotericin B [Svahn et al., 2015]. It was also established that 12 species of fungi of the genus Penicillium, isolated ecological niches of Arctic and Antarctic are producers of BAS of different structural types (including alkaloids), which found to have inherent antibacterial, antifungal, anticancer and others properties [Антипова, 2009]. Increased lithogenic activity was shown for microscopic mycelium fungus Geomyces pannorum, isolated from Antarctic habitats. This feature of these micromycetes metabolism thought to be associated with survival strategy under conditions of stress (extreme) environmental factors [Konova et al., 2009]. Broad prospects are accepted on undergoing ability of fungi to «super synthesis» of lipids in technical fields, including for biodiesel using waste of agriculture, food industry, etc. [Феофилова, 2007; Ткачевская и др., 2007]. Capacity of exhibit antibacterial and antifungal activity to synthesize a series of compounds found to be present in bacteria isolated from Antarctic samples can be used in the biotechnology industry (pharmaceutical, food industries, etc.). Exopolysaccharides of these microorganisms can be used as biological agents in the processes of detoxification of soils contaminated by petroleum or oil products [Poli et al., 2010; Anitori, 2012; Papa et al., 2013; Asencio et al., 2014].

So, given the urgency of issues highlighted above, the purpose of our work is to search producers of BAS among diversity of Antarctic organisms (bacteria, yeasts, filamentous fungi), to establish their biological characteristics and to replenish the collection of technologically advanced microorganisms by new taxa.

\section{Materials and methods of research}

The examples of mosses, lichens, soil and stones (the Galindez, Pitterman, Yalur Islands) obtained during 18-20th Ukrainian Antarctic expeditions were used as material for our research (Fig. 1). 
T. O. Kondratiuk, T. V. Beregova, L. I. Ostapchenko DIVERSITY OF ANTARCTIC MICROORGANISMS - POTENTIAL PRODUCERS OF BIOLOGICALLY ACTIVE SUBSTANCES
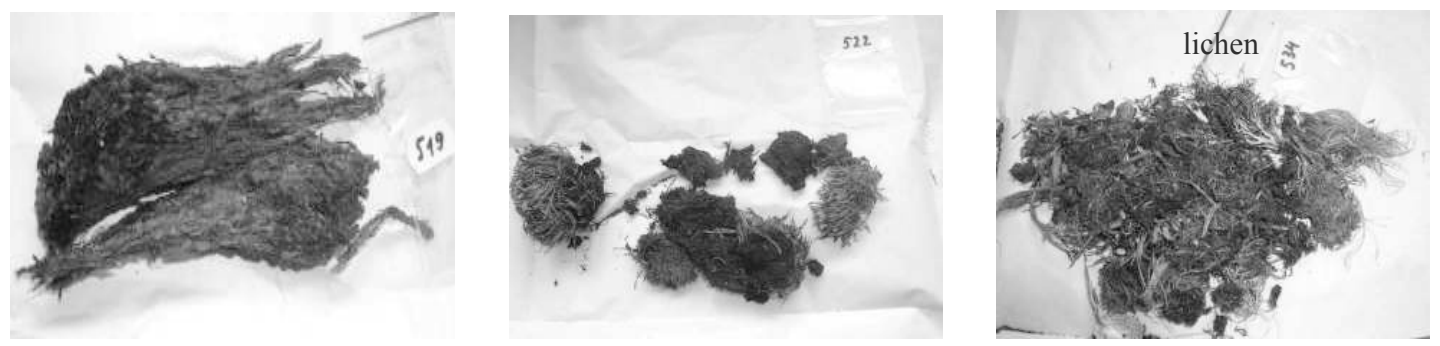

Fig. 1. Samples of moss, lichens and soil that was used for research

Standard microbiological methods for culturing on agar and liquid nutrient media: Malt extract agar (MEA), Malt extract broth (MEB), Nutrient Agar (Na), Nutrient broth (NB), agar Chapek-Dox, potatodextrose agar (PDA) [Samson et al., 2004], Saburo environment, Tryptic Soy broth (TSB) and others (Production of «Farmaktyv», Ukraine; Merck KGaA, Germany; HiMedia Laboratories, India and others.) were performed for getting pure cultures of microorganisms from Antarctic samples. Evaluation of growth on agar media was performed visually (pronounced presence or absence of colonies of microorganisms in batch culture). Modern methods of identification of isolated microorganisms and determination of their characteristics (cultural-morphological and physiological-biochemical) were used. Determining physiological and biochemical characteristics and identity of cultures of bacteria was conducted using appropriate ID-cards and microbiological analyzer «Vitek-2» ( «Bio Merieux», France). Morphological features of microorganisms (the study of cells and spores) was done using binocular microscopes Primo Star Company carl Zeiss. Trinocular microscope Primo Star company Carl Zeiss (equipped with the appropriate video camera) was also used for photographing and the preparations required measurement parameters (diameter of the cells and spores of microorganisms, the distance between cells, etc). Morphometric Computer program AxioVision 4.8 (Carl Zeiss) was performed. Scanning electron microscopy (SEM JSM-6060LA, Japan) was also used.

\section{Results and Discussion}

25 pure cultures of microscopic fungi that referred to the divisions Zygomycota (species of Mortiriella, Mucor), Ascomycota (Eurotium sp.) And a group Anamorphic fungi (the genera Cladosporium, Fusarium, Geotrichum, Geomyces, Penicillium, Phoma, Rhodotorula) were isolated from the samples of mosses, lichens, soil and stones obtained from 18-20th Ukrainian Antarctic expeditions. Among them microscopic fungi with a pronounced activity to the synthesis of complex bioactive lipids, fatty acids deserve special attention. The following taxa, i.e.: Geomyces pannorum (Link) Sigler \& J. W. Carmich. (today it is a synonym of Pseudogymnoascus pannorum (Link) Minnis \& D.R. Lindner)) and a representative of the order Mucorales Mucor circinelloides Tiegh. found to be present among cultures isolated (Fig. 2.3).
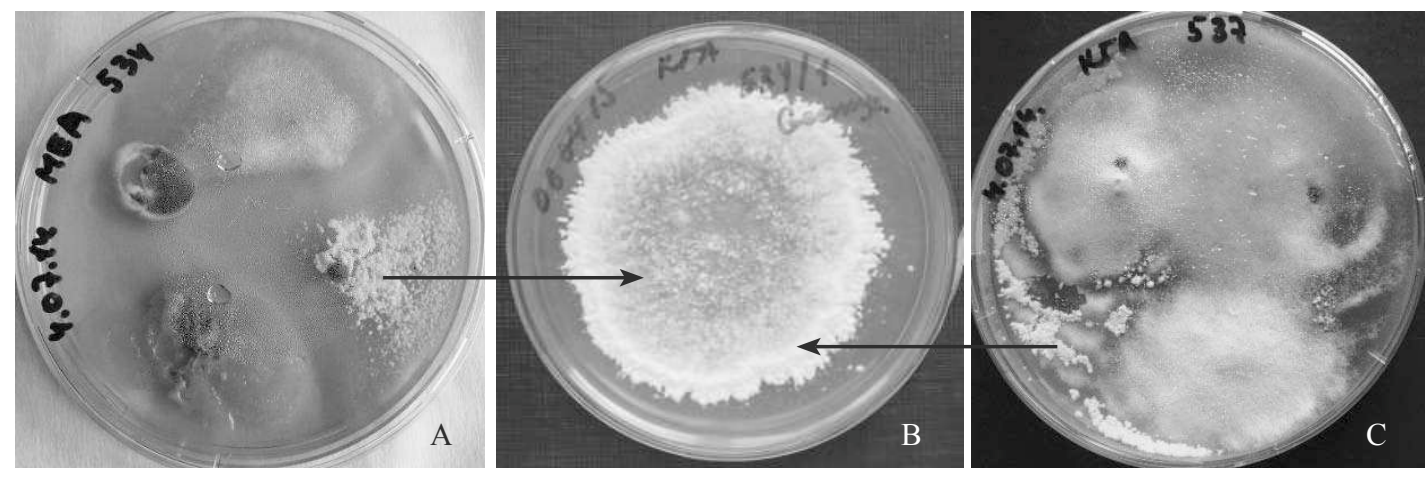

Fig. 2. Microscopic fungus Pseudogymnoascus pannorum (A, C - in batch culture, B - pure culture), isolated from Antarctic moss samples. 
The microscopic fungi Mucor circinelloides and Pseudogymnoascus pannorum found to have ability to synthesize and accumulate lipids in lipid hyphae in the form of granules, particles (Fig. 3). The optimal conditions for the synthesis of biologically important lipids can be established by identifying the fatty acid composition of lipids of these fungi on different nutrient media. The latter can be used for the synthesis of antibiotics as energy sources (biodiesel) to create medicines that contain of essential fatty acids and ubiquinone Q-9. The possibility of cultivation of microorganisms in the waste of agricultural and food industry makes them convenient and cost-effective in the usage [Tauk-Tornisielo et al., 2009; Bhanja et al., 2014].
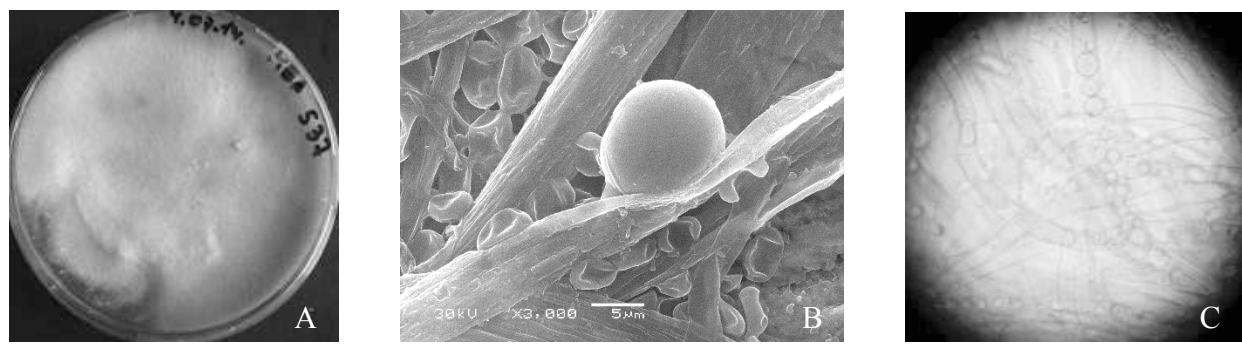

Fig. 3. Microscopic fungus Mucor circinelloides (A, B) from Antarctic moss samples, $\mathrm{C}-$ lipid granules in hyphae of $M$. circinelloides, $\times 400$

The microscopic fungi of the genus Penicillium, which known that they are producers of 380 secondary metabolites with biological activity, were isolated from Antarctic samples studied too (Fig. 4). The alkaloids pruducing by fungi of the genus Penicillium, which widely used in medicine [Антипова, 2009] have particular practical interest.
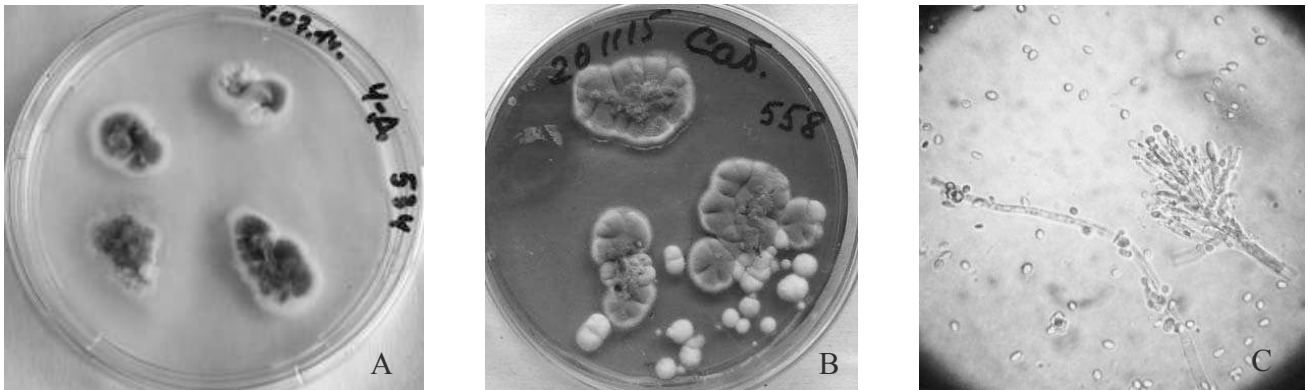

Fig. 4. Fungi of the genus Penicillium, isolated from Antarctic soil samples (A) and mosses (B and C). C $-\times 400$

Visually clearly visible sterile zone around the microorganisms in batch culture (Fig. 5) were registered during the study of the Antarctic samples. Among the samples studied we selected 8 pure cultures of bacteria that synthesize biologically active substances that can inhibit the growth of other microorganisms (they show pronounced antagonistic properties).
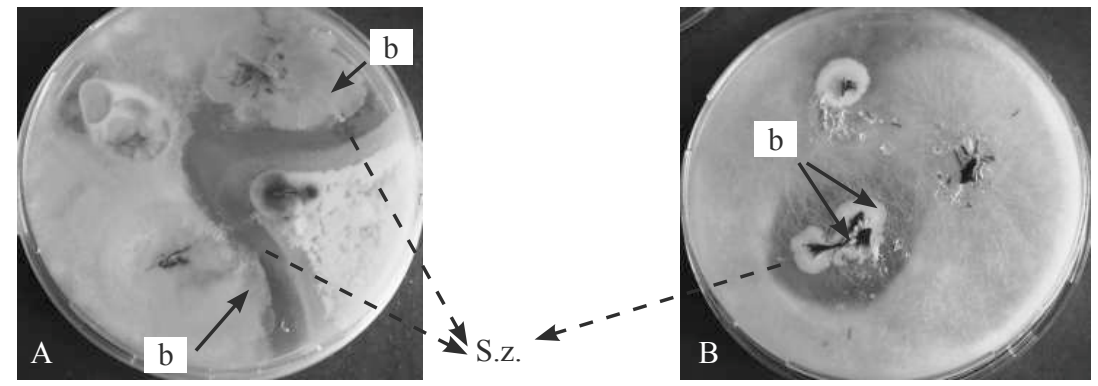

Fig. 5. Bacteria from Antarctic samples in batch cultures (A, B - the other side of Petri dishes); $\mathrm{b}$ - colonies of bacteria that inhibit the growth of the mycelium of fungi;

S. z. - Sterile zones that are formed around colonies of bacteria antagonists. 
T. O. Kondratiuk, T. V. Beregova, L. I. Ostapchenko

DIVERSITY OF ANTARCTIC MICROORGANISMS - POTENTIAL PRODUCERS OF BIOLOGICALLY ACTIVE SUBSTANCES

Gram-positive and gram-negative bacilli, and spore producing species found to be present among the selected bacteria (Fig. 6).
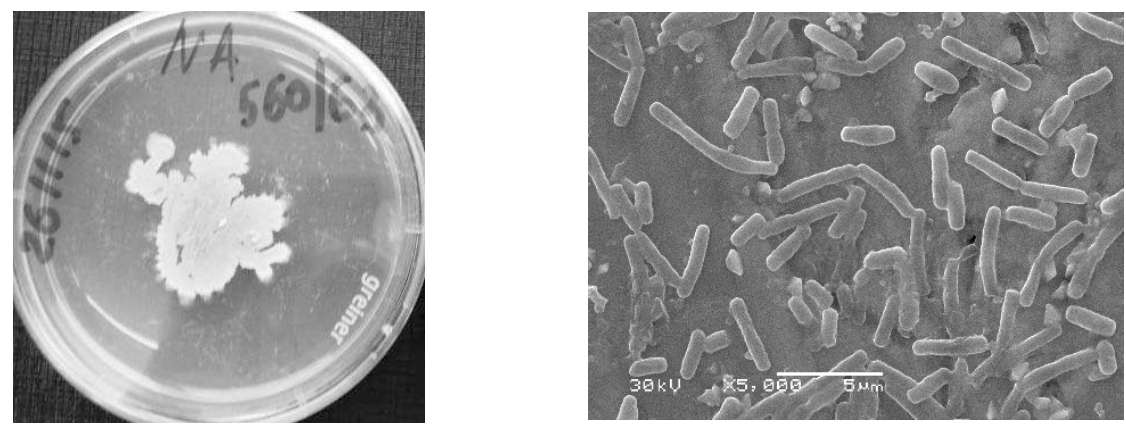

Fig. 6. Pure culture of spore producing bacteria from Antarctic samples

A number of physiological and biochemical characteristics of isolated bacterial cultures were revealed using microbiological analyzer Vitek-2 (table).

Physiological and biochemical characteristics of bacteria isolated from Antarctic samples

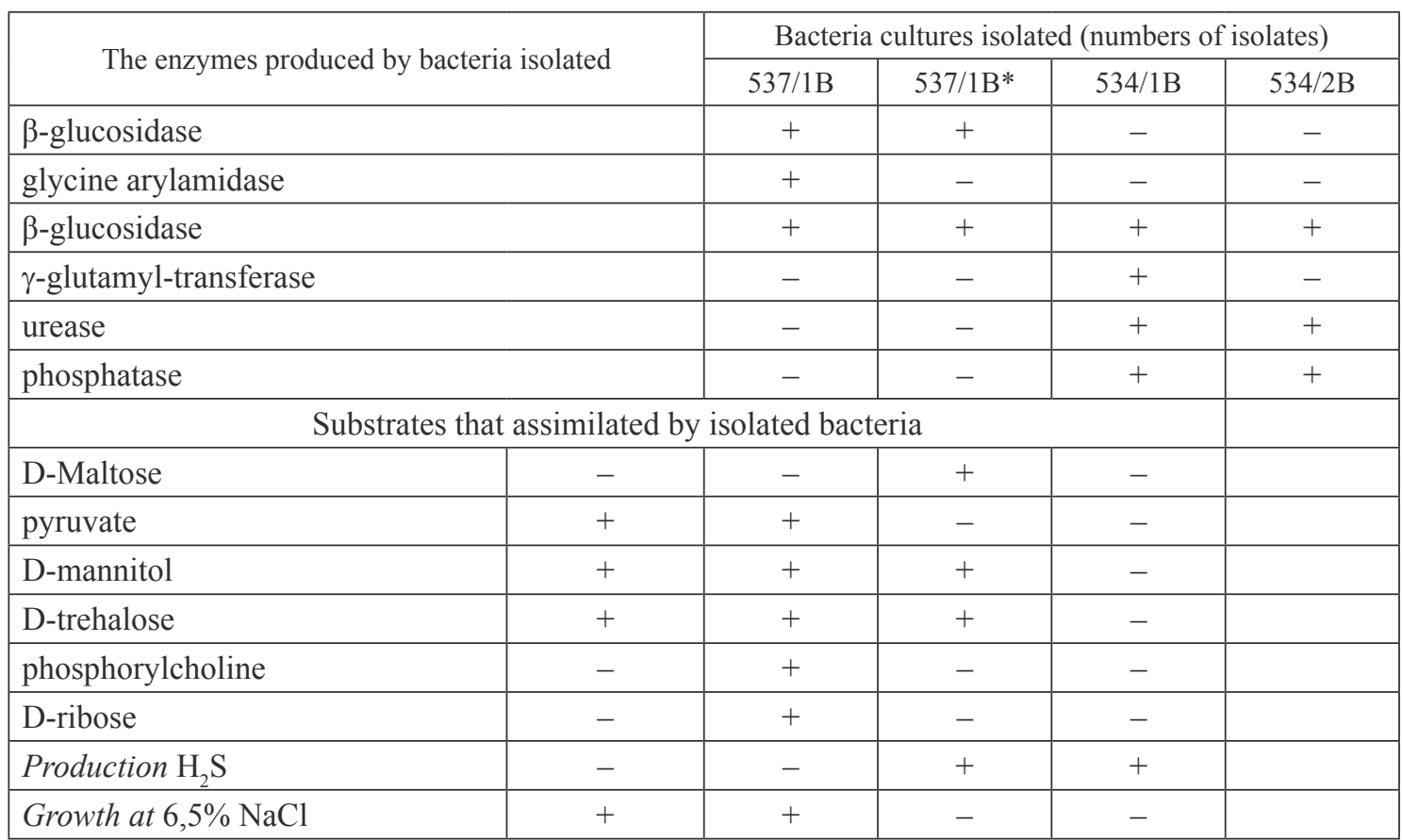

Taxonomic identity of the two cultures of bacteria, i.e.: Bacillus sp. (Isolate 537/1B) and Sphingobacterium thalpophilum (isolate 534/2B) was proved by established morphological and physiological-biochemical features.

Our data on the properties of antagonistic bacteria of the genus Bacillus are consistent with the results of other authors who studied members of this genus of bacteria isolated from different environments with extreme conditions of existence [Ali et al., 2014]. Bacteria of the genus Sphingobacterium, isolated from Antarctic samples are of interest as potential producers of carotenoids, including beta-carotene, and sphingophospholipids [Jagannadham, et al., 2000; Kaneshiro et al., 1996]. Established that bacteria psyhrotolerant Sphingobacterium antarcticus are able to synthesize carotenoids in much larger quantities 
at temperature $5^{\circ} \mathrm{S}$ than mesophilic S. multivorum at the temperature $25^{\circ} \mathrm{S}$ [Jagannadham, et al., 2000 ]. Thus, the genus Sphingobacterium, isolated us from Antarctic samples is of interest as potential producers BAS.

\section{Conclusions}

As a result of our studies collection of technologically advanced microorganisms is replenished with new species of microscopic fungi and bacteria - producers of BAS.

Our results and literature data indicate the need for further research to establish the chemical structure of BAS of isolated microorganisms.

\section{Acknowledgement}

The authors thank V. I. Sapsay (Kyiv) for help in conducting research on the scanning electron microscope, P.P. Zelena and O.O. Morgaienko - for help in conducting research using microbiological analyzer Vitek-2 and Gram staining procedure; National Antarctic center of MES of Ukraine for financial support to research (Contract number 15DF036-06 / H / 12-2015).

\section{References}

1. Антипова Т. В. Штаммы-реликты грибов рода Penicillium как продуценты вторичных метаболитов // Автореф. дис. к.б.н. - 2009. - 22 с.

2. Феофилова Е. П. Новые биотехнологии получения биологически активних веществ из мицелиальных грибов //Успехи медицинской микологии. - 2007. - Т.IX. - С. 195 - 196.

3. Ткачевская Е. П., Конова И. В., Сергеева Я. С. и др. Новые направления практического использования олеагенных грибных микроорганизмов (p. Cuningamella и др.) в получении биодизеля и для модификации синтетических полимеров //Успехи медицинской микологии. - 2007. - Т. IX. - С. $190-194$.

4. Ali S., Hameed S., Imran A. et al. Genetic, physiological and biochemical characterization of Bacillus sp. strain RMB7 exhibiting plant growth promoting and broad spectrum antifungal activities // Microb. Cell Fact. 2014. - V. 13. - P. $144-159$.

5. Asencio Geraldine, Lavin Paris, Alegría Karen et al. Antibacterial activity of the Antarctic bacterium Janthinobacterium sp. SMN 33.6 against multi-resistant Gram-negative bacteria //Electron. J. Biotechnol. - 2014. V. 17. - no.1. - P. $1-5$.

6. Bhanja A., Minde G., Magdum S., Kalyanraman V. Comparative studies of oleaginous fungal strains ( $M u$ cor circinelloides and Trichoderma reesei) for effective wastewater treatment and bio-oil production // Biotechnol. Res. Int. - 2014. - Vol. (2014). - P. 1 - 7.

7. Henriquez M., Cháves R., Vaga I.Antarctic fungi: Sources of new chemical substances with antibacterial properties //Chilean Antarctic Bulletin. - 2013. - 13 (1-2). - P. 12.

8. Jagannadham M. V., Chattopadhyay M.K., Subbalakshmi C. et al. Carotenoids of an Antarctic psychrotolerant bacterium, Sphingobacterium antarcticus, and a mesophilic bacterium, Sphingobacterium multivorum // Arch. Microbiol. - 2000. - 173 (5-6). - P. $418-24$.

9. Kaneshiro T., Nakamura L. K., Bagby M. O. Oleic acid transformations by selected strains of Sphingobacterium thalpophilum and Bacillus cereus from composted manure //Current microbiology -1996. - V. 31, Is.1. - P. $62-67$.

10. Konova I. V., Sergeeva Ia. E., Galanina L. A. et al. Lipid synthesis by Geomyces pannorum under the impact of stress factors // Mikrobiologiia. - 2009 - V. 78 (1). - P. $52-58$.

11. Kostadinova N., Krumova E., Tosi S. et al. Isolation and Identification of Filamentous Fungi from Island Livingston, Antarctica // Biotechnology and Biotechnological Equipment, Special Issue: XI Anniversary scientific conference. - 2009. - V. 23, Supplement 1. - P. $267-270$.

12. Margesin R., Fauster V., Fonteyne P.A. Characterization of cold-active pectate lyases from psychrophilic Mrakia frigida. // R. Margesin, // Lett. Appl. Microbiol. - 2005. - 40(6). - P. 453 - 459.

13. Nai C., Wong H. Y., Pannenbecker A. et al. Nutritional physiology of a rock-inhabiting, model microcolonial fungus from an ancestral lineage of the Chaetothyriales (Ascomycetes) // Fungal Genet. Biol. - 2013. - 56. P. $54-66$.

14. Papa R., Parrilli E., Sannino F. et al. Anti-biofilm activity of the Antarctic marine bacterium Pseudoalteromonas haloplanktis TAC125 // Res. Microbiol. - 2013. - 164 (5). - P. 450 - 456. 
T. O. Kondratiuk, T. V. Beregova, L. I. Ostapchenko DIVERSITY OF ANTARCTIC MICROORGANISMS - POTENTIAL PRODUCERS OF BIOLOGICALLY ACTIVE SUBSTANCES

15. Poli Annarita, Anzelmo Gianluca, Nicolaus Barbara Bacterial Exopolysaccharides from Extreme Marine Habitats: Production, Characterization and Biological Activities // Mar Drugs. - 2010. - 8(6). - P. 1779 - 1802.

16. Roberto Paul Anitori Extremophiles: Microbiology and Biotechnology. - 2012. - 300 p.

17. Samson R. A., Hoekstra E. S., Frisvad J. C. Introduction to food and airborne fungi. 7th edit. - Wageningen, the Netherlands, printed by Ponsen and Looyen, 2004. - 389 p.

18. Svahn S. K., Olsen B., Bohlin L. et al. Penicillium nalgiovense Laxa isolated from Antarctica is a new source of the antifungal metabolite amphotericin B //Fungal Biology and Biotechnology. - 2015. - 1. - P. $2-11$.

19. Tauk-Tornisielo S. M., Arasato L. S., de Almeida A. F. et al. Lipid formation and $\gamma$-linolenic acid production by Mucor circinelloides and Rhizopus sp., grown on vegetable oil // Brazilian Journal of Microbiology. 2009. - Vol. 40. - P. 342 - 345. 